\title{
EFFECT OF ADDING GINGER POWDER OR GINGER OIL ON PRODUCTIVE PERFORMANCE OF EWES DURING LACTATION PERIOD
}

\author{
S. Abo Bakr \\ Animal and Poultry Nutrition Department, Animal and Poultry Nutrition Division, Desert Research \\ Center, P.O. Code 11753 Mataria, Cairo, Egypt.
}

(Received 8/1/2019, accepted 26/2/2019)

\section{SUMMARY}

$\mathrm{T}$ his experiment was carried out at Research Station of Maryout belonging to Desert Research Center to assess the effect of ginger forms (Zingiber officinale) on productive performance, rumen and blood parameters of Barki ewes. Forty Barki ewes at last pregnant stage, aged 3-4 year and average weighed $40.47 \mathrm{~kg} \pm 0.99$, were fed concentrate mixture and alfalfa hay (as traditional ration) and divided into four equal groups. $1^{\text {st }}$ group (T1) fed traditional ration without any supplementation as control group, the $2^{\text {nd }}$ (T2) and $3^{\text {rd }}$ (T3) groups fed control ration with 3 or $6 \mathrm{gm}$. Ginger powder (GP)/head/day, respectively. The $4^{\text {st }}$ (T4) fed control ration plus $2 \mathrm{ml} / \mathrm{head} /$ days of ginger oil (GO). Rations offered were adjusted according to ewe's weight and nutrient requirements. Results revealed that treatments had no significant effect on live body weight changes and total dry matter intake. Milk yield affect significantly $(\mathrm{P}<0.05)$ of adding ginger forms. T2 (Low GP) recorded the highest $(\mathrm{P}<0.05)$ value of milk production compared to experimental groups and control which recorded the lowest value. Experimental treatments significantly $(\mathrm{P}<0.05)$ affect milk fat and total soiled percentage. Ewes in T2 (3 gm. GP/h/d.) group recorded the highest values of milk component except fat. Feeding ewes on experimental treated rations led to decrease saturated fatty acids (C 12:0 and C16:0), While, the experimental groups (except T2) insignificantly increased milk unsaturated fatty acids and conjugated linoleic acids. Treatments of ginger forms insignificantly affect $\mathrm{pH}$ and total volatile fatty acids. While, T4 decreased $(\mathrm{P}<0.05)$ ammonia concentration and protozoa population compared to other groups. Results of blood biochemical were differ significantly $(\mathrm{P}<0.05)$ as affected by experimental treatments. $\mathrm{T} 3$ recorded the highest values of total proteins and globulin as compared to other groups. Total lipids and triglyceride values were higher for T4 than other groups. Data of lamb's performance showed that birth and weaning weights of kids didn't appear any significant differences among groups. On the other hand, T3 and T2 lambs recorded the highest $(\mathrm{P}<0.05)$ daily gain. Finally, T3 was better economic evaluation than other groups, where recoded the best feed conversion and net revenue for farmers.

Keywords: Barki sheep, ginger powder, ginger oil, milk production and composition, rumen and blood parameters.

\section{INTRODUCTION}

Small ruminants in Egypt serve as investment and insurance due to their characteristics such as high fertility, short generation interval and adaptation to the arid and semi-arid conditions (Khalil et al., 2013). In the desert rangeland areas of Egypt Barki sheep are raised as a resource of income for the Bedouin and kept for meat production and numbered 470,000 heads (El-Bassiony 2016).

One of the most important challenges of animal production in the harsh desert conditions is the shortage of feed to meet the nutritional requirements of these herds as well as the high costs of transporting feed to the desert area (Helal et al., 2018).

Many procedures have been used to enhance animal productivity such as feed additives (Nassar et al., 2017). However, research indicated that chemical feed additives can cause unfavorable side-effects and hazards to animals and humans (Schwarz et al., 2001). This may be due to their harmful residues in milk and meat, which threaten health (Russell and Houlihan 2003). For that, The World Health Organization (WHO) 


\begin{abstract}
Abo Bakr
recommends and encourages the using of natural feed additives to avoid side effect of unnatural additives (Mohamed et al., 2003).

Medical plants (such as ginger) and their extracts are wieldy accepted and used as feed additives to improve productivity and immunity of livestock, without negative residues effects in milk and meat in addition to saving to human health and consumers (Zanouny et al., 2013).

Ginger (Zingiber officinale) has been shown to have antioxidant, anti-inflammatory, and anti-bacterial properties (Williams and Lamprecht, 2008). Also, ginger natural plant extracts contain some secondary metabolites, which have shown antimicrobial activity (Zhang, et al., 2011).

During early weeks of lambs' life, suckling milk considered the main source of nutrition for them (ElGhousein, 2010). Moreover, colostrum is very important and considered the sole source of initial acquired immunity for offspring (Stelwagen et al., 2009 and Alves et al., 2015). Also, both rumen and blood parameters are very important indicators for animal productivity and immunity.

The objective of the present study was to evaluate the effect of using ginger forms (powder or oil) as feed additives on the productive performance of Barki sheep.
\end{abstract}

\title{
MATERIALS AND METHODS
}

Experimental location: The present study was conducted in Maryout Research Station, Desert Research Center (DRC), Ministry of Agriculture and Land Reclamation, Egypt. This station located $35 \mathrm{~km}$ south of Alexandria governorate, Egypt. This study lasted for sixteen weeks (four weeks in late pregnancy period followed by other twelve weeks in lactation period).

Animals and rations: Forty pregnant Barki ewes, aged 3-4 year and average weighed $40.47 \mathrm{~kg} \pm 0.99$, were allocated to four feeding regimes in a complete randomize (10 animals each). All experimental ewes were fed concentrate mixture design to live body weight and alfalfa hay according to physiological status as recommended by Kearl (1982). Roughage concentrate ratio was 40:60 in the last 4 weeks of pregnancy, 50:50 during first 4 weeks of lactation and 60:40 in the last 8 weeks of lactation. Animal groups received one of four dietary treatments. The treatments were: $1^{\text {st }}$ group (T1) without any additives (Control). The $2^{\text {nd }}$ (T2) and $3^{\text {rd }}$ (T3) groups were treated with 3 and $6 \mathrm{gm}$. ginger powder (GP)/head/day, respectively. Ginger powder was mixed daily by concentrate mixture to offer for daily basis. The $4^{\text {st }}$ (T4) group was orally administered by $2 \mathrm{ml}$ ginger oil (GO) / head/ day. All experimental animals were weighed biweekly till the end of lactation period. Clean fresh water was offered twice daily. The kids were numbered and individually weighed biweekly from birth to weaning.

Sampling and analysis of milk: Five ewes from each group were randomly chosen to record milk parameters. In the next day of parturition, colostrum samples were taken and kept for analysis. Milk production was recorded biweekly starting from the second week of lambing till the $12^{\text {th }}$ week of lactation using the hand-milking procedure after separation of lambs from their dams. Milk samples were taken and kept in plastic bottles under $-20{ }^{\circ} \mathrm{C}$ for chemical analysis. Chemical compositions of milk, in terms of fat, protein, lactose, total solids and solids not fat were determined by using milk scan (MilkoScan, Bentley, Belguim).

Sampling and analysis of rumen liquor: Rumen liquor samples were collected from animals during the mid- lactation period by using a stomach tube at three hours post feeding. The rumen samples were filtered through two layers of cheese-cloth and $\mathrm{pH}$ values were recorded immediately by digital $\mathrm{pH}$-meter. Rumen samples were stored frozen $\left(-18^{\circ} \mathrm{C}\right)$ for later analysis. Samples of protozoal count were preserved and counted as described by the method of Dehority (1984).

Sampling and analysis of blood: During mid-lactation period blood samples were taken randomly from five animals from group. Blood samples were withdrawn. Then, centrifuged and separated blood serum was stored into a clean dried glass vial at $-20^{\circ} \mathrm{C}$ for analysis. Biochemical analyses (total proteins, albumin, urea, creatinine, aspartate transaminase (AST), alanine transaminase (ALT), alkaline phosphatase (ALP), total lipids and cholesterol) were measured in serum using kits provided by Diamond Company. Immunoglobulin (IgG) was measured by ELISA kits after serum dilution and according to Abbott Laboratories instruction (Abbotta Park, IL 60064 USA. Gamma-Glutamyl Transferrase (GGT) was determined by using kinetic 
colorimetric methods and commercial kits supplied by Spectrum-Diagnostics Egypt Company for Biotechnology. Lipid fraction in blood was assessed by measuring triglyceride concentration (Hatch and Lees, 1968 and Raltiff and Hall, 1973).

Analytical methods: Proximate analyses of concentrate mixture and alfalfa hay (Table 1) were determined according to AOAC (2007).

Table (1): Chemical composition of concentrate mixture (CM) and alfalfa hay.

\begin{tabular}{lrccccccc}
\hline Item & \multicolumn{7}{c}{ Composition \% on DM } \\
\cline { 2 - 9 } & DM & OM & CP & EE & CF & NFE & Ash & TDN $^{*}$ \\
\hline CM & 91.08 & 91.05 & 16.11 & 2.70 & 16.54 & 55.70 & 8.95 & 67.99 \\
Alfalfa hay & 91.33 & 87.50 & 15.54 & 1.94 & 31.97 & 38.05 & 12.5 & 56.53 \\
\hline
\end{tabular}

*TDN: Total digestible nutrient for alfalfa hay and CFM were estimated according to Adams et al., 1964.

Ammonia nitrogen in the rumen fluid was determined according to A.O.A.C. (2007). Total volatile fatty acids (TVFA's) were determined according to Warner (1964).

Statistical analysis: Data obtained in this study was statistically analyzed by one way of variances according to SAS (2004) using the following model; $\mathrm{Y}_{\mathrm{ij}}=\mu+\mathrm{T}_{\mathrm{i}}+\mathrm{e}_{\mathrm{ij}}$, Whers; $\mathrm{Y}_{\mathrm{ij}}=$ experimental observation, $\mu=$ overall mean, $\mathrm{T}_{\mathrm{i}}=$ effect of treatment, $\mathrm{e}_{\mathrm{ij}}=$ experimental error. Differences among means were compared by Duncan's multiple range Test of Duncan (1955).

\section{RESULTS AND DISCUSSION}

Voluntary feed intake: The present findings of total dry matter intake during different production periods showed that there were no differences among groups (Table 2), because nutrient requirements were given (restricted feeding) as a results of changing in body weight and physiological status according to kearl (1982). The results in the current study were in agreement with Noaman and Shujaa (2016) who observer that no significant differences in intake for lambs fed ration supplemented with different dosages of GP. Also, Aylin and Kocabali (2014) stated that DM intake was not affected by supplying different dosages of oregano oil to lambs rations.

On the other hand, Shams Al-dain, and Jarjeis (2015) observed significant increases in daily intake for cows fed rations supplemented with high and low doses of GP.

Table (2): Voluntary feed intake of ewes fed tested rations during late pregnancy and lactation period.

\begin{tabular}{lcccc}
\hline \multirow{2}{*}{ Item } & \multicolumn{4}{c}{ Experimental group } \\
\cline { 2 - 5 } Total intake* in last 4 weeks of pregnancy & 1489.6 & 1489.4 & 1490.2 & 1510.2 \\
Total intake in first 4 weeks of lactation & 1764.0 & 1617.4 & 1637.6 & 1772.0 \\
Total intake in last 8 weeks of lactation & 1300.2 & 1177.2 & 1222.0 & 1310.4
\end{tabular}

T1: control ration, T2: control ration plus $3 \mathrm{gm}$. of GP/h/d, T3: control ration plus $6 \mathrm{gm}$. of GP/h/d, T4: control ration plus $2 \mathrm{ml} / \mathrm{h} / \mathrm{d}$ of ginger oil.

*Roughage concentrate ratio was 40:60 in the last 4 weeks of pregnancy, 50:50 during first 4 weeks of lactation and 60:40in the last 8 weeks of lactation.

Live body weight changes of ewes: Results of ewes live body weight changes revealed that there were no significant differences among the experimental groups (Table 3). Just before and after kidding, high weight 
was recorded in T4 followed by T1. These may be due to higher birth weights of their lambs (Table 12). While, ewes received GP recorded less weights (T2 and T3, respectively) than others. During early lactation phase, all ewes lost their weight compared to weights at after kidding where, ewes of T1 showed the higher loss but their mates in $\mathrm{T} 2$ have lower loss weight.

Generally, it was noticeable that treated with ginger forms recorded the less lost weights in early lactation phase compared to their mates in control group. These results were in agreement with those obtained by Shams Al-dain and Jarjeis (2015) they indicated that control group was more lost weights than cows treated by 75 or $150 \mathrm{~g}$ of $\mathrm{GP} / \mathrm{h} / \mathrm{d}$.

Average weights of ewes during milk production in all groups there did not differ significantly (Table 3). Generally, the data of ewes weights during different stages of lactation indicated that no significant effects on live weight. This might be due to the feeds were proposed to cover the requirements of milk production for each all animal. These results were in agreement with those obtained by Shams Al-dain and Jarjeis (2015) they indicated there were no significant effects of adding different dosages from GP to experimental rations on live weight without adverse effect on dairy cows during different periods.

Table (3): Body weight changes (kg) of ewes fed tested rations during late pregnancy and lactation period.

\begin{tabular}{lccccc}
\hline \multirow{2}{*}{ Item } & \multicolumn{5}{c}{ Experimental group } \\
\cline { 2 - 6 } & $\mathrm{T} 1$ & $\mathrm{~T} 2$ & $\mathrm{~T} 3$ & $\mathrm{~T} 4$ & $\pm \mathrm{SE}$ \\
\hline During late pregnancy period & & & & \\
Initial body weight & 40.26 & 40.25 & 40.27 & 40.82 & 1.19 \\
Just before kidding & 47.56 & 46.12 & 45.60 & 48.00 & 1.49 \\
Just after kidding & 42.00 & 38.51 & 38.98 & 42.19 & 1.59 \\
Weight in early lactation & 35.92 & 35.24 & 33.24 & 37.12 & 1.29 \\
Weight in mid lactation & 36.30 & 33.76 & 34.06 & 36.28 & 1.25 \\
Weight in late lactation & 33.98 & 29.92 & 32.02 & 34.58 & 1.18 \\
Average weight during lactation period & 35.40 & 32.94 & 33.10 & 36.00 & 1.18
\end{tabular}

T1: control ration, T2: control ration plus $3 \mathrm{gm}$. of GP/h/d, T3: control ration plus $6 \mathrm{gm}$. of GP/h/d, T4: control ration plus $2 \mathrm{ml} / \mathrm{h} /$ d of ginger oil.

Milk yield: Results of milk yield during different weeks of lactation appeared that the first two weeks of lactation recorded the highest milk yield value as compared with other periods of lactation (Figure 1).

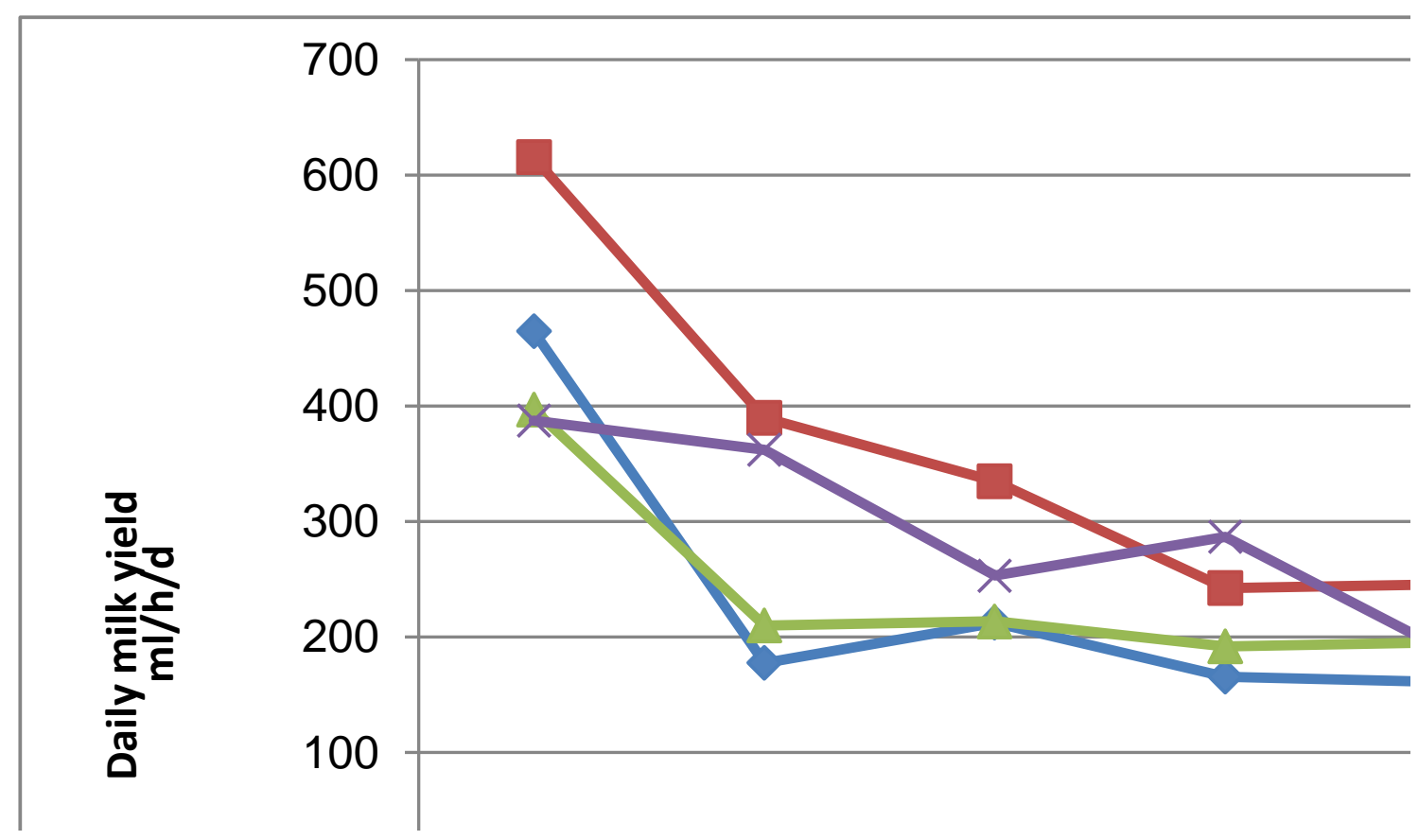


Average milk yield at 4,8, 12 week of lactation and during all periods (Table 4) demonstrated that addition of ginger forms to ewes' rations led to a significant $(\mathrm{P}<0.05)$ increase in milk yield only during early lactation compared with control. However, during mid and late lactation periods, there were insignificantly increases. These increase in milk production of treated ewes may be due the addition of ginger products (GP or GO) which led to high propionate ratio and reducing methane production (Patra and Saxena, 2010). Moreover, Hameed et al. (2012) recorded increases in milk production of Holstein cows fed rations supplemented by different levels of GP as compared to those in control. Adding GO led to higher milk production than control group. These results were in agreement with those obtained by Kholif et al. (2012), who found increased milk production of goats fed ration added daily with $2 \mathrm{ml} \mathrm{GO}$ when compared to ration without addition.

Table (4): Milk yield of ewes fed tested rations during lactation period.

\begin{tabular}{|c|c|c|c|c|c|}
\hline \multirow{2}{*}{ Item } & \multicolumn{4}{|c|}{ Experimental group } & \multirow{2}{*}{$\pm \mathrm{SE}$} \\
\hline & $\mathrm{T} 1$ & $\mathrm{~T} 2$ & T3 & $\mathrm{T} 4$ & \\
\hline Average daily milk yield $(\mathrm{ml} / \mathrm{h} / \mathrm{d})$ & & & & & \\
\hline First 4 weeks & $271.2^{\mathrm{b}}$ & $502.8^{\mathrm{a}}$ & $303.6^{\mathrm{ab}}$ & $375 . .0^{\mathrm{ab}}$ & 35.7 \\
\hline Second 4weeks & 189.0 & 288.6 & 202.8 & 270.0 & 21.6 \\
\hline Third 4 weeks & 148.2 & 218.8 & 175.8 & 191.4 & 14.3 \\
\hline Average during 12 weeks & $202.8^{\mathrm{b}}$ & $336.8^{\mathrm{a}}$ & $227.4^{\mathrm{ab}}$ & $278.8^{\mathrm{ab}}$ & 22.1 \\
\hline
\end{tabular}

The obtained results demonstrated that addition of different forms of ginger increased significantly $(\mathrm{P}<0.05)$ average total milk yield as compared with control. Ewes fed $3 \mathrm{gm}$. of GP (T2) had the highest $(\mathrm{P}<0.05)$ milk yield followed by ewes fed $2 \mathrm{ml}$ of GO (T4) then those fed $6 \mathrm{mg}$ of GP (T3). The lowest value was recorded for ewes fed control ration (T1).

Increasing milk yield with of ewes fed ginger forms (T2, T3 and T4) may be due to one or more of the following reasons which correlated to using ginger as a dietary additives; the degradability of DM and natural detergent fiber were improved with mixture of ginger and garlic oils compared with control (Nanon et al., 2014), improvement of nitrogen, energy utilization, feed efficiency and ruminants healthy (Giannenas et al., 2013) and finally, increasing saliva secretion and enhancement bile acids synthesis in the liver which have positive effects on digestion and absorption of lipids (Kumar et al., 2014).

Chemical composition of colostrum: Addition of ginger to ewes' rations resulted in significant differences $(\mathrm{P}<0.05)$ in all colostrum composition component except for protein percentage (Table 5). Regarding fat percentage, the $4^{\text {th }}$ treatment $(\mathrm{GO})$ had higher $(\mathrm{P}<0.05)$ fat $(\%)$ as compared to other experiment treatments. However, there were no significant differences among T1, T2 and T3 (Table 5). This result agreed with (Smeti et al. 2015) who found that increasing in fat colostrum for ewes was due to supplying essential oils compared to other groups

Table (5): Chemical composition of colostrum for ewes fed tested rations during lactation period.

\begin{tabular}{|c|c|c|c|c|c|}
\hline \multirow{2}{*}{ Item } & \multicolumn{4}{|c|}{ Experimental group } & \multirow{2}{*}{$\pm \mathrm{SE}$} \\
\hline & T1 & $\mathrm{T} 2$ & T3 & $\mathrm{T} 4$ & \\
\hline Fat $(\%)$ & $7.93^{b}$ & $7.28^{b}$ & $6.89^{b}$ & $11.83^{\mathrm{a}}$ & 0.58 \\
\hline Protein $(\%)$ & 11.17 & 9.15 & 10.27 & 8.47 & 0.45 \\
\hline Lactose $(\%)$ & $2.66^{\mathrm{c}}$ & $4.63^{\mathrm{b}}$ & $2.25^{\mathrm{c}}$ & $6.71^{\mathrm{a}}$ & 0.27 \\
\hline Total Solids (\%) & $39.22^{\mathrm{a}}$ & $30.45^{\mathrm{b}}$ & $33.97^{\mathrm{b}}$ & $30.07^{\mathrm{b}}$ & 1.09 \\
\hline Solids Not Fat (\%) & $16.25^{\mathrm{a}}$ & $14.45^{\mathrm{b}}$ & $15.58^{\mathrm{ab}}$ & $14.25^{\mathrm{b}}$ & 0.28 \\
\hline
\end{tabular}

On an opposite trend, Hendawy et al. (2019) noted that adding $5 \mathrm{~g} / \mathrm{h} / \mathrm{d}$ of GP to ewes' rations do not affect colostrum composition except total solids which was higher with GP adding. 
Nevertheless, the obtained percentages of fat, protein and lactose were within the range reported by Banchero et al. (2004) with values being (8.2 to 10.6) for fat (\%), (7.7 to 15.7) for protein (\%) and (1.7 to 3.6) for lactose $(\%)$.

Generally, the composition and quality of colostrum was more affected by their nutrition (Hyrslova et al., 2016).

Chemical composition of milk: Data in Table (6) showed significant $(\mathrm{P}<0.05)$ effect of GP and GO during the first four weeks of lactation on fat and solids not fat percentages compared to control group. However, no significant effects were noticed on protein, lactose, total solids and ash. Fat percentage differed $(\mathrm{P}<0.05)$ among groups and the highest value was recorded for T3. These results agreed with Hendawy et al. (2019) where adding $5 \mathrm{~g} \mathrm{GP} / \mathrm{h} / \mathrm{d}$ to ewes' ration increased fat of milk which may be due to high efficiency of ruminal activity and increasing acetic acid production and acetate propionate ratio in the rumen. On the other hand, the lowest value of fat percentage was in T4. Kholif et al., (2012) concluded that reduction in milk fat for goats fed essential oils additives compared with the control group, which may be due to the lower ruminal acetate proportion and acetate to propionate ratio for control group.

On the other hand, solids not fat showed significant differences $(\mathrm{P}<0.05)$ among groups and the highest value was in T2 followed by T4. The data of milk composition in mid lactation didn't reflect any significant effects in all components for rations supplemented with ginger forms.

Table (6): Chemical composition (\%) of ewes milk fed tested rations during different lactation period.

\begin{tabular}{|c|c|c|c|c|c|}
\hline \multirow{2}{*}{ Item } & \multicolumn{4}{|c|}{ Experimental group } & \multirow{2}{*}{$\pm \mathrm{SE}$} \\
\hline & $\mathrm{T} 1$ & $\mathrm{~T} 2$ & T3 & $\mathrm{T} 4$ & \\
\hline \multicolumn{6}{|l|}{ First 4 weeks } \\
\hline Fat & $2.96^{\mathrm{b}}$ & $2.58^{\mathrm{c}}$ & $3.40^{\mathrm{a}}$ & $1.87^{\mathrm{d}}$ & 0.05 \\
\hline protein & 2.39 & 2.88 & 2.58 & 2.72 & 0.05 \\
\hline lactose & 3.81 & 4.27 & 3.87 & 4.04 & 0.06 \\
\hline Total Solids & 9.59 & 10.58 & 10.40 & 9.44 & 0.14 \\
\hline Solids Not Fat & $6.63^{\mathrm{b}}$ & $8.00^{\mathrm{a}}$ & $7.00^{\mathrm{ab}}$ & $7.56^{\mathrm{ab}}$ & 0.11 \\
\hline Ash & 0.42 & 0.84 & 0.54 & 0.79 & 0.01 \\
\hline \multicolumn{6}{|l|}{ Second 4 weeks } \\
\hline Fat & 2.65 & 2.49 & 2.07 & 1.47 & 0.17 \\
\hline protein & 2.81 & 2.66 & 2.54 & 2.67 & 0.08 \\
\hline lactose & 4.20 & 3.86 & 3.86 & 4.35 & 0.10 \\
\hline Total Solids & 10.47 & 9.37 & 9.22 & 9.24 & 0.21 \\
\hline Solids Not Fat & 7.82 & 7.24 & 7.15 & 7.76 & 0.22 \\
\hline Ash & 0.80 & 0.72 & 0.74 & 0.73 & 0.07 \\
\hline \multicolumn{6}{|l|}{ Third 4 weeks } \\
\hline Fat & $2.15^{\mathrm{a}}$ & $2.51^{\mathrm{a}}$ & $2,50^{\mathrm{a}}$ & $0.82^{b}$ & 0.15 \\
\hline protein & 2.47 & 2.88 & 2.56 & 2.56 & 0.13 \\
\hline lactose & 3.61 & 4.56 & 3.85 & 4.19 & 0.38 \\
\hline Total Solids & $9.15^{\mathrm{b}}$ & $10.81^{\mathrm{a}}$ & $9.66^{\mathrm{ab}}$ & $8.08^{b}$ & 0.58 \\
\hline Solids Not Fat & 7.00 & 8.30 & 7.16 & 7.25 & 0.46 \\
\hline Ash & $0.91^{\mathrm{a}}$ & $0.85^{\mathrm{ab}}$ & $0.75^{\mathrm{ab}}$ & $0.50^{\mathrm{b}}$ & 0.12 \\
\hline \multicolumn{6}{|c|}{ Average chemical composition during lactation period } \\
\hline Fat & $2.58^{\mathrm{a}}$ & $2.53^{\mathrm{a}}$ & $2.66^{\mathrm{a}}$ & $1.39^{\mathrm{b}}$ & 0.05 \\
\hline protein & 2.56 & 2.81 & 2.56 & 2.65 & 0.06 \\
\hline lactose & 3.87 & 4.23 & 3.86 & 4.19 & 0.14 \\
\hline Total Solids & $9.74^{\mathrm{ab}}$ & $10.37^{\mathrm{a}}$ & $9.76^{\mathrm{ab}}$ & $9.82^{b}$ & 0.14 \\
\hline Solids Not Fat & 7.15 & 7.85 & 7.10 & 7.53 & 0.19 \\
\hline Ash & 0.71 & 0.80 & 0.68 & 0.68 & 0.04 \\
\hline
\end{tabular}


During late lactation period, there were significant differences in milk composition. T2 (Low GP) achieved higher values of all tested components than other groups while T4 (GO) had the lowest fat, total solids and ash percentages.

The date of milk composition during different periods reflected on average chemical analysis of milk. T2 (Low GP) recorded the highest values of all except fat. On the hand, T4 (GO) recorded lower fat $(\mathrm{P}<0.05)$ and total solids $(\%)$ and higher lactose, protein and solids not fat (\%). The lower milk fat percentage may be due to the reduction ruminal acetate proportion and acetate to propionate ratio in ewes' rumen. While, improving milk protein with GO may be increasing microbial protein synthesis. Similar results were obtained by Spanghero et al. (2008) who reported that adding essential oils to animals feed had increased the milk protein percentage. Higher milk lactose in $\mathrm{T} 2$ and $\mathrm{T} 4$ may be due to ginger products addition led to decrease blood glucose (Ahmide and Abuzogaya, 2009).

The present results were in consistent with those of Hendawy et al. (2019). They stated that adding GP to ewes' ration improved milk fat and TS percentages with no effect on values of milk protein, SNF and lactose when compared to control group suggesting that the improvement in milk quality may be caused by the enhancement in the immune response of farm animals.

Milk fatty acids profile: The obtained data (Table 7) showed that feeding ewes low dosage of GP (T2) decreased both of C8:0 and C10:0 fatty acids. On the other hand, Benchaar et al. (2007) found no variations in milk fatty acids when supplementing the ration of dairy cows with a mixture of essential oils compounds.

Also, data showed that feeding ewe's tested ration which contained GO (T4) led to decrease milk fatty acids; $\mathrm{C}_{12: 0}$ and $\mathrm{C}_{16: 0}$ compared with other rations. This reduction might be because of the potential inhibitory effect of the dietary polyunsaturated fatty acids (PUFA) or its metabolites on the nova fatty acids synthesis in the mammary gland (Allam et al., 2012 and Kedegowda et al., 2009) or a dilution effect.

Feeding ewes on GP or GO ration were insignificantly increased the content of milk from $\mathrm{C}_{18}$ fatty acids. These results agree with findings of Allam et al., (2012). The increase of $\mathrm{C}_{18: 1}$ for ewes milk fed experimental ration may be resulted from partial bio-hydrogenation of $\mathrm{C}_{18: 2}$ and $\mathrm{C}_{18: 3}$ fatty acids and the desaturation of $\mathrm{C}_{18: 0}$ in the mammary gland (Kennelly,1996).

Feeding GP (T2) and GO (T4) induced a higher content of C20:0 than control group, while T3 recorded the lowest value. This results were in agreement with Kholif et al. (2012) who reported that GO increased C20:0 fatty acid, unsaturated fatty acids and conjugated linoleic acid (CLA) in lactating goats fed ration supplemented with garlic, cinnamon or ginger oils.

Table (7): Milk fatty acids profile of ewes fed tested rations during lactation period.

\begin{tabular}{|c|c|c|c|c|c|}
\hline \multirow{2}{*}{ Item } & \multicolumn{4}{|c|}{ Experimental group } & \multirow{2}{*}{$\pm \mathrm{SE}$} \\
\hline & $\mathrm{T} 1$ & $\mathrm{~T} 2$ & T3 & $\mathrm{T} 4$ & \\
\hline \multicolumn{6}{|l|}{ Saturated fatty acids } \\
\hline C8:0(Caprlyic acid) & $0.60^{\mathrm{b}}$ & $0.14^{\mathrm{c}}$ & $0.89^{\mathrm{a}}$ & $0.68 \mathrm{a}^{\mathrm{b}}$ & 0.08 \\
\hline C10:0(Capric acid) & $4.49^{\mathrm{a}}$ & $1.47^{\mathrm{b}}$ & $4.30^{\mathrm{a}}$ & $3.83^{\mathrm{a}}$ & 0.36 \\
\hline C12:0(Lauric acid) & $3.25^{\mathrm{b}}$ & $4.33^{\mathrm{a}}$ & $2.69^{b}$ & $2.38^{\mathrm{b}}$ & 0.25 \\
\hline C14:0(Myristi acid) & $8.34^{\mathrm{a}}$ & $5.51^{\mathrm{b}}$ & $8.70^{\mathrm{a}}$ & $7.50^{\mathrm{a}}$ & 0.42 \\
\hline C15:0(Pentadecanoie acid) & $1.79^{\mathrm{a}}$ & $0.67^{\mathrm{b}}$ & $1.07 \mathrm{ab}$ & $1.36 \mathrm{a}$ & 0.13 \\
\hline C16:0(Palmtic acid) & $26.81^{\mathrm{a}}$ & $22.15^{\mathrm{b}}$ & $27.06^{\mathrm{a}}$ & $24.31^{\mathrm{b}}$ & 0.66 \\
\hline C16:1 $\omega 7$ (Palmitioleic acid) & $1.37 \mathrm{a}^{\mathrm{b}}$ & $1.46^{\mathrm{a}}$ & $1.27^{\mathrm{b}}$ & $1.30^{\mathrm{b}}$ & 1.83 \\
\hline C17:0(Heptadeeanoic acid) & $1.55^{\mathrm{a}}$ & $0.80^{\mathrm{b}}$ & $0.88^{\mathrm{b}}$ & $0.99^{\mathrm{b}}$ & 0.10 \\
\hline C18:0(Stearic acid) & $15.63 \mathrm{a}$ & $12.93 \mathrm{~b}$ & $14.50 \mathrm{ab}$ & $15.06 \mathrm{ab}$ & 0.43 \\
\hline \multicolumn{6}{|l|}{ Unsaturated fatty acids } \\
\hline 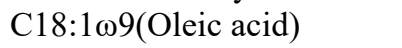 & $23.57^{\mathrm{b}}$ & $33.42^{\mathrm{a}}$ & $28.25^{\mathrm{ab}}$ & $28.30^{\mathrm{ab}}$ & 1.36 \\
\hline 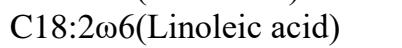 & $4.05^{\mathrm{bc}}$ & $12.92^{\mathrm{a}}$ & $3.70^{\mathrm{c}}$ & $5.73^{\mathrm{b}}$ & 1.14 \\
\hline 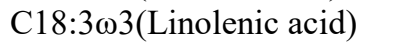 & 0.33 & 0.60 & 0.48 & 1.05 & 0.13 \\
\hline C20:0(Arechidic acid) & $0.34^{\mathrm{ab}}$ & $0.43^{\mathrm{a}}$ & $0.26^{\mathrm{b}}$ & $0.39^{\mathrm{a}}$ & 0.02 \\
\hline C20:1 $\omega 5$ (Eicosaenoic acid) & $0.38^{\mathrm{a}}$ & $0.34^{\mathrm{a}}$ & $0.36^{\mathrm{a}}$ & $0.23^{\mathrm{a}}$ & 0.02 \\
\hline
\end{tabular}


In the present result, $\mathrm{C} 18: 1 \omega 9, \mathrm{C} 18: 2 \omega 6$ and $\mathrm{C} 18: 2 \omega 3$ were insignificantly increased compared with control group. In similar trend Boutoial et al. (2013) indicated that addition extracts of rosemary leaves to lactating goats increased Polly unsaturated fatty acids as the dosage of extracts increased.

\section{Ruminal parameters:}

pH value: Data in Table (8) declared that there were no significant differences in $\mathrm{pH}$ values as a result of feeding ewes on rations supplied with the experimental additives. In similar, Zhang et al. (2011) reported that no significant differences were observed as a result of feeding GP. Moreover, Kholif et al. (2012) found that ruminal $\mathrm{pH}$ levels didn't differ significantly between animals fed treated ration by $2 \mathrm{ml} / \mathrm{h} / \mathrm{d}$ of $\mathrm{GO}$ and control. While, Al-Khayat (2011) reported a decrease in the rumen $\mathrm{pH}$. Generally, the mean $\mathrm{pH}$ values of rumen liquor in the present study are within the ranges reported by Rakha (1988) and El Ashry et al., (1997). Furthermore, the $\mathrm{pH}$ values were always above 6.0 which ensure of maximal celluloalytic activity and microbial protein synthesis as reported by Hungate (1966).

Total volatile fatty acids concentration: The concentrations of TVFA were not significantly affected by the tested rations. Also, Patra et al., (2010) found that extracts of ginger had no effect on the TVFA concentration. On the other hand, Zhang et al (2011) reported that TVFA concentration decreased by increasing the ginger powder dose in rations.

Table (8): Effect of tested rations on rumen parameters during lactation period.

\begin{tabular}{|c|c|c|c|c|c|}
\hline \multirow{2}{*}{ Item } & \multicolumn{4}{|c|}{ Experimental group } & \multirow{2}{*}{$\pm \mathrm{SE}$} \\
\hline & $\mathrm{T} 1$ & $\mathrm{~T} 2$ & T3 & $\mathrm{T} 4$ & \\
\hline $\mathrm{Ph}$ & 6.13 & 6.33 & 6.25 & 6.20 & 0.28 \\
\hline TVFA,s (meq/100 ml RL) & 5.20 & 5.20 & 5.40 & 5.37 & 0.05 \\
\hline $\mathrm{NH}_{3}-\mathrm{N}(\mathrm{mg} / 100 \mathrm{ml} \mathrm{RL})$ & $18.62^{\mathrm{a}}$ & $18.70^{\mathrm{a}}$ & $17.72^{\mathrm{a}}$ & $15.05^{\mathrm{b}}$ & 0.46 \\
\hline Protozoa (X $10^{5}$ cell $\mathrm{ml}^{-1}$ ) & $4.85^{\mathrm{a}}$ & $4.72^{\mathrm{a}}$ & $4.37^{\mathrm{a}}$ & $2.17^{\mathrm{b}}$ & 0.35 \\
\hline
\end{tabular}

${ }^{a, b}$ means at the same row with different superscript are significantly $(P<0.05)$ different. T1: control ration, T2: control ration plus $3 \mathrm{gm}$. of GP/h/d, T3: control ration plus $6 \mathrm{gm}$. of $\mathrm{GP} / \mathrm{h} / \mathrm{d}$, T4: control ration plus $2 \mathrm{ml} / \mathrm{h} / \mathrm{d}$ of ginger oil.

Ammonia nitrogen concentration: Values of ruminal $\mathrm{NH}_{3}-\mathrm{N}$ (Table 8) showed significant $(\mathrm{P}<0.05)$ differences between $\mathrm{T} 4$ (which recorded the lowest value) and other groups. Generally, lower $\mathrm{NH}_{3}-\mathrm{N}$ concentration in $\mathrm{T} 4$ (GO group ) This could be explained with the influence of essential oils additives as moderate in absorbing and subsequently releasing ammonia nitrogen in the rumen (Castillejos et al., 2008). Furthermore, Ferme et al. (2004) found a reduction in $\mathrm{NH}_{3}-\mathrm{N}$ concentration by the essential oils that might be modified the microbial population profile in a continuous culture experiment and decreased the contribution of Prevotella spp which is mainly responsible for protein degradation and amino acids deamination suggesting a mode of action of essential oils on protein metabolism The present results agreed with those obtained by Busquet et al. (2006) when used GO.

Ruminal Protozoa population: In this study, there was a significant $(\mathrm{P}<0.05)$ difference between $\mathrm{T} 4$ (highly decrease in protozoa count) and other groups (Table 8). A reduction in total protozoa number in G4 may be due to the presence of antiprotozoal activities of ginger components (Agarwal., et al 2009) and also, essential oils ingredient in GO reduced methane produced by selectively inhibiting protozoa (Sallam et al., 2011). Regardless of T4, results showed that no significant differences were occurred between control and other groups (T2 and T3). These results were in harmony with those observed by Al-Azazi et al. (2018).

\section{Blood biochemical parameters:}

Data in Table (9) showed that total proteins, albumin, globulin and A/G ratio differed significantly $(\mathrm{P}<0.05)$ as affected by experimental rations as compared to control group. Total proteins increased in T3 which may be due to that GP enhanced the secretion of saliva, the efficiency of digestion enzymes, the digestion and metabolism and slow the time of feed passage which increased the absorption of protein in small intestine (Platel and Sirnivasan, 2001 and Suresh and Srinivasan, 2007). Furthermore, Shams Al-dain, and Jarjeis (2015) and El-Gohary et al. (2012) found that total proteins tended to be higher with GP addition for Friesian dairy cows and goats rations, respectively. Alternatively, Al-Azazi et al., (2018) concluded that 
addition of herbal mixture to sheep feed had no consequence effects on total serum proteins. The lowest value of total proteins recorded via T4 (GO addition), which might be attributed to that the essential oils modified the microbial population profile, decreasing the contribution of Prevotella spp, which is mainly responsible for protein degradation and amino acids deamination suggesting a mode of action of essential oils on protein metabolism (Ferme et al. 2004).

The values of albumin showed significant $(\mathrm{P}<0.05)$ differences among rations (Table 9). The highest serum albumin value was in ration supplemented with GO (T4) while the lowest value recorded by control group (T1). These results may be owing to the improvements of ruminal microbial protein synthesis or to the decrease in milk non protein nitrogen which increased milk protein and blood albumin (Kholif et al., 2012).

Table (9): Effect of tested rations on blood biochemical parameters of ewes during lactation period.

\begin{tabular}{lccccc}
\hline \multirow{2}{*}{ Item } & \multicolumn{4}{c}{ Experimental group } & \multirow{2}{*}{ \pm SE } \\
\cline { 2 - 4 } & $\mathrm{T} 1$ & $\mathrm{~T} 2$ & $\mathrm{~T} 3$ & $\mathrm{~T} 4$ & 0.25 \\
Total protein $(\mathrm{g} / \mathrm{dl})$ & $7.84^{\mathrm{ab}}$ & $7.55^{\mathrm{b}}$ & $8.68^{\mathrm{a}}$ & $6.36^{\mathrm{c}}$ & 0.14 \\
Albumin (g/dl) & $4.01^{\mathrm{b}}$ & $4.47^{\mathrm{ab}}$ & $4.36^{\mathrm{ab}}$ & $4.98^{\mathrm{a}}$ & 0.31 \\
Globulin (g/dl) & $3.82^{\mathrm{ab}}$ & $3.06^{\mathrm{b}}$ & $4.31^{\mathrm{a}}$ & $1.38^{\mathrm{c}}$ & 0.30 \\
A:G Ratio & $1.07^{\mathrm{b}}$ & $1.54^{\mathrm{b}}$ & $1.02^{\mathrm{b}}$ & $3.70^{\mathrm{a}}$ & 0.15 \\
IgG* (IU/L) & $0.97^{\mathrm{b}}$ & $1.12^{\mathrm{b}}$ & $2.28^{\mathrm{a}}$ & $1.50^{\mathrm{b}}$ & \\
\hline a, b, c means at the same row with different superscript are significantly (P<0.05) different. T1: control ration, T2: control \\
ration plus 3 gm. of GP/h/d, T3: control ration plus 6 gm. of GP/h/d, T4: control ration plus 2 ml/h/d of ginger oil. \\
*IgG: Immunoglobulin.
\end{tabular}

Concerning globulin values, the results demonstrated that $\mathrm{T} 3$ had higher $(\mathrm{P}<0.05)$ globulin value than other treated (T2 and T4) groups. This increment in GL of T3 might be attributed to the presence of active components in ginger powder which brought about boom cellular antioxidant defenses activity, act as antilammation and induced improved immune response of the body and subsequently globulin was increased (Zancan et al. 2002 and Fawzi et al. 2009). On the other hand, the lowest values of globulin were in T4. This result agreed with Kholif et al. (2012) who found that decreasing globulin value with adding GO compared to control group.

Animals fed experimental ginger rations had higher IGG than control group. The highest value was recorded in T3 followed by $\mathrm{T} 4$ while the lowest value recorded for $\mathrm{T} 1$ (control group). This might be attributed to the effect of medicinal plants which improve the immunity and able to cause changes of the duodenal mucosa with beneficial effects for the animal (Lavinia et al., 2009).

Lipids profile: The results of total lipids (TLs) values showed significant $(\mathrm{P}<0.05)$ increase in animals fed ration contained GO (T4). There were no significant differences among other groups. The control group had higher TLs values than that of T2 and T3 (Table 10). These results were in agreement with those reported by Zeweil et al. (2016) that adding linseed oil plus GP lowered total lipids values than control group.

Table (10): Effect of tested rations on lipids profile of ewes during lactation period.

\begin{tabular}{|c|c|c|c|c|c|}
\hline \multirow{2}{*}{ Item } & \multicolumn{4}{|c|}{ Experimental group } & \multirow{2}{*}{$\pm \mathrm{SE}$} \\
\hline & $\mathrm{T} 1$ & $\mathrm{~T} 2$ & T3 & $\mathrm{T} 4$ & \\
\hline Total lipids (mg/dl) & $37.18^{b}$ & $25.67^{b}$ & $24.78^{\mathrm{b}}$ & $101.79^{\mathrm{a}}$ & 9.37 \\
\hline Triglyceride(mg/dl) & $37.92^{\mathrm{b}}$ & $30.52^{\mathrm{b}}$ & $33.03^{\mathrm{b}}$ & $48.17^{\mathrm{a}}$ & 2.04 \\
\hline Cholesterol(mg/dl) & 54.41 & 59.33 & 50.64 & 52.59 & 2.85 \\
\hline
\end{tabular}

$\overline{a, b}$, means at the same row with different superscript are significantly $(P<0.05)$ different. T1: control ration, T2: control ration plus $3 \mathrm{gm}$. of GP/h/d, T3: control ration plus $6 \mathrm{gm}$. of $\mathrm{GP} / \mathrm{h} / \mathrm{d}$, T4: control ration plus $2 \mathrm{ml} / \mathrm{h} / \mathrm{d}$ of ginger oil,

The values of triglyceride had the same trend of TLs where animals fed GO (T4) had higher $(\mathrm{P}<0.05)$ triglyceride concentration than those for other experimental groups. Moreover, control group also, exceeded insignificantly the concentrations of triglyceride of $\mathrm{T} 3$ and $\mathrm{T} 2$, as showed in Table (10). The reduction 
observed in triglyceride for rations supplemented with GP (T2 and T3) may be due to the influences of GP on liver tissues and benefit in metabolism. The same results were clarified with Noaman and El-Rawy (2013). Whilst, increasing value of triglyceride in T4 may be due to the negative effect of GO on rumen microflora activity (as indicated early in Table 8) and digestion. Bianchi et al. (2014) found significant increase in triglyceride level in dairy sheep fed different level of palm oil.

The present findings demonstrated that the lowest value of serum cholesterol level was in T3 followed by T4 compared to other experimental groups. Decreasing cholesterol in T3 may be due to higher dosage of GP. Shewita and Taha (2018) found that adding ginger (6 g GP/kg diet) lowered cholesterol concentrations. Kholif et al. (2012) reported that essential oil supplementation to goat's rations decreased cholesterol concentrations compared with those fed control.

On the other hand, Al-jubori (2017) suggested that addition of $25 \mathrm{~g} / \mathrm{h} / \mathrm{d}$ ginger powder to ewes ration led to increase the cholesterol concentration in blood.

Kidney and liver function: Serum urea concentration in this study decreased significantly $(\mathrm{P}<0.05)$ in $\mathrm{T} 4$ and insignificant differences among control, T2 and T3 (Table 11). Nassar et al. (2017) reported that decrease in urea concentration as a result of inhibition effect of garlic oil on deamination and lower ruminal ammonia concentration. On the other hand, Noaman and Al-Rawe (2013) recoded no significant differences between urea concentrations of Awassi lambs fed rations with or without different dosages of ginger powder.

Animal fed control ration recorded significant $(\mathrm{P}<0.05)$ decrees for creatinine value $(1.80)$ compared with the experimental rations (Table 11). The present results are in accordance with Ibrhim (2015) who reported that insignificant increasing in creatinine value for ewes which given water with ginger extract in comparison to control.

Table (11): Effect of tested rations on Kidney and liver function of ewes during lactation period.

\begin{tabular}{|c|c|c|c|c|c|}
\hline \multirow{2}{*}{ Item } & \multicolumn{4}{|c|}{ Experimental group } & \multirow{2}{*}{$\pm \mathrm{SE}$} \\
\hline & $\mathrm{T} 1$ & $\mathrm{~T} 2$ & $\mathrm{~T} 3$ & $\mathrm{~T} 4$ & \\
\hline Urea $(\mathrm{mg} / \mathrm{dl})$ & $81.40^{\mathrm{a}}$ & $76.34^{\mathrm{a}}$ & $82.41^{\mathrm{a}}$ & $67.76^{b}$ & 1.74 \\
\hline Createnine $(\mathrm{mg} / \mathrm{dl})$ & $1.80^{\mathrm{c}}$ & $2.39^{\mathrm{b}}$ & $2.63^{\mathrm{ab}}$ & $2.92^{\mathrm{a}}$ & 0.11 \\
\hline ALT(IU/L) & $41.00^{c}$ & $49.00^{\mathrm{a}}$ & $48.00^{\mathrm{ab}}$ & $47.00^{\mathrm{b}}$ & 0.08 \\
\hline AST(IU/L) & $62.00^{\mathrm{b}}$ & $70.00^{\mathrm{a}}$ & $72.00^{\mathrm{a}}$ & $65.00^{\mathrm{b}}$ & 0.13 \\
\hline ALP(IU/L) & $4.59^{\mathrm{b}}$ & $6.15 \mathrm{a}$ & $5.08^{\mathrm{a}}$ & $5.81^{\mathrm{a}}$ & 0.44 \\
\hline GGT(IU/L) & $24.07^{\mathrm{b}}$ & $26.13^{\mathrm{ab}}$ & $30.65^{\mathrm{a}}$ & $28.92^{\mathrm{ab}}$ & 0.95 \\
\hline
\end{tabular}

The obtained results of AST, ALT and ALP activity in blood serum of ewes demonstrated that there were significant $(\mathrm{P}<0.05)$ decreases for $\mathrm{T} 1$ compared to other treated groups (Table 11). Ibrhim (2015) reported that ewes given ginger extract have higher AST and lower ALT than control. On the other hand, Kholif et al. (2012) mentioned that no significant effects of adding ginger on the activity of AST and ALT enzymes were recorded.

\section{Lamb's performance:}

Birth and weaning weights of kids are present in Table (12). The birth weight of lambs didn't appear any significant differences and ranged from 3.34 to 3.82 for T3 and T1, respectively. Generally, birth weight of lambs is affected by different factors such as year of birth, sexing, maternal litter size (Gardner et al., 2007) and other such as body condition score of dams, previous nutritional status of ewes.

Also, the weaning weight was insignificant among groups. But weaning weights for T2 and T3 groups (rations with GP) were over than T1 by 12.0 and $24.5 \%$, respectively. While the lowest weaning weights recoded by T1 and T4. This variation may be due to variation in milk production as shown in Table (4). 
Table (12): Effect of tested rations on birth, weaning weight and daily gain.

\begin{tabular}{|c|c|c|c|c|c|}
\hline \multirow{2}{*}{ Item } & \multicolumn{4}{|c|}{ Experimental group } & \multirow{2}{*}{$\pm \mathrm{SE}$} \\
\hline & $\mathrm{T} 1$ & $\mathrm{~T} 2$ & T3 & $\mathrm{T} 4$ & \\
\hline Birth weight (Kg) & 3.82 & 3.69 & 3.34 & 3.73 & 0.10 \\
\hline Weaning weight(Kg) & 12.59 & 14.10 & 15.67 & 12.68 & 0.55 \\
\hline Total gain $(\mathrm{Kg})$ & $8.77^{\mathrm{b}}$ & $10.41^{\mathrm{ab}}$ & $12.33^{\mathrm{a}}$ & $8.94^{\mathrm{b}}$ & 0.54 \\
\hline Average daily gain(gm.) & $125.40^{\mathrm{b}}$ & $148.76^{\mathrm{ab}}$ & $167.21^{\mathrm{a}}$ & $127.67^{\mathrm{b}}$ & 0.35 \\
\hline
\end{tabular}

Higher weaning weight of ewe fed ginger powder levels (T3 and T2) reflected on total gain and average daily gain. Hence, T3 and T2 ewes varied significantly and exceeded their counterparts of control group by $40.5 \%$ and $18.7 \%$ (for total gain), $33.3 \%$ and $18.6 \%$ (for average daily gain), respectively, compared with control ones. These findings may be due to that ginger increased the absorption of essential nutrients for ewes and reflected on improving the growth of the kids (Belewu, 2006) or higher milk production in the same groups as presented in Table (4). It is little known about the effect of adding ginger forms on offspring birth weight and daily weight gain from birth to weaning.

Commonly, the observed data of average daily gain was within the normal range on Barki lambs weight observed by Ibrahim et al. (2018) and El-Bassiony (2016) being 173 and $157 \mathrm{~g} / \mathrm{h} / \mathrm{d}$ respectively. Also, Nassar et al. (2017) reported that minimum average daily gain for the same breed was $105 \mathrm{~g} / \mathrm{h} / \mathrm{d}$. The results of the present study revealed that addition of ginger products had a positive effect on growth performance of lambs.

\section{Economical Evaluation:}

The obtained findings revealed that the best feed conversions expressed as DMI/gain were recorded for T3 followed by T2 then the worst by T4. Also, the best milk conversion expressed as litter suckling milk $/ \mathrm{kg}$ gain were better for experimental ration than control group (Table 13).

It was worthy to mention that T3 was the cheapest feed cost per kg gain. This result may be due to higher gain of the animals of this group compared with others, while T4 showed the highest feeding cost as a result of the price of GO and the lowest total gain.

Table (13): Feed efficiency and economical evaluation of ewes during lactation periods.

\begin{tabular}{lcccc}
\hline Item & \multicolumn{4}{c}{ Experimental group } \\
\cline { 2 - 4 } & T1 & T2 & T3 & T4 \\
\hline Feed conversion & & & & \\
Kg DMI/litter milk & 2.57 & 2.44 & 2.40 & 2.80 \\
Litters of suckling milk/kg gain & 4.35 & 3.48 & 3.56 & 3.85 \\
Daily feed and additives cost LE/h/d & & & \\
Roughage & 2.49 & 2.27 & 2.33 & 2.51 \\
CFM & 3.15 & 2.88 & 2.94 & 3.17 \\
Ginger powder & 0 & 0.21 & 0.42 & 0 \\
Ginger oil & 0 & 0 & 0 & 4.00 \\
Total cost & 5.65 & 5.36 & 5.69 & 9.68 \\
Price of ADG & 8.78 & 10.41 & 11.70 & 8.94 \\
Return from selling ADG & 3.13 & 5.05 & 6.01 & -0.74 \\
Feed cost / kg gain & 45.06 & 36.03 & 34.03 & 75.82 \\
Return from selling kg gain & 24.94 & 33.97 & 35.97 & -5.82 \\
Net revenue as \% & 100 & 136 & 144 & -23
\end{tabular}

T1: control ration, T2: control ration plus $3 \mathrm{gm}$. of GP/h/d, T3: control ration plus $6 \mathrm{gm}$. of GP/h/d, T4: control ration plus $2 \mathrm{ml} / \mathrm{h} / \mathrm{d}$ of ginger oil.

Besides, the obtained resulted demonstrated that the highest feed cost.kg gain was recorded for T4 due to higher price of GO (2000 LE/L), however, the obtained gain in live weight didn't cover this cost. On the 
other hand, the ration of control group (T1) (without any additives) had lower feed cost but it also had lower in total gain. Subsequently, higher price of GO reflected on the profit from gain and led to negative return from selling live weight and the highest gain in T3 and T2 led to higher the profit. The present results are in accordance with Hameed et al. (2012) who found that higher net revenue for treated cows (50 gm. GP/h/d) by $25 \%$ than untreated cows.

\section{CONCLUSION}

From the previous data it can be concluded that addition of ginger powder could be used to improve milk production, and its positively effect on milk fatty acids, had positive effects on blood parameters, improve the immunity of animals, led to higher total and average daily gain and increase the net revenue for farmers. However, a lot the nutritional effects of ginger (meat production and carcasses) need to be validated using proper studies.

\section{REFERENCES}

AOAC (2007). Association of Official Analytical Chemists. Official Methods of analysis, $19^{\text {th }}$ Edition, Washington, USA.

Adams, R.S.; J.H. Moore; E.M. Kesler; and G.Z. Stevens (1964). New relationships for estimating TDN content of forages from chemical composition. J. Dairy Sci., 47: 436-441.

Agarwal, N.; C. Shekhar; R. Kumar; L. Chaudhary and D. Kamra, (2009). Effect of peppermint (Mentha piperita) oil on in vitro methanogenesis and fermentation of feed with buffalo rumen liquor. Anim. Feed Sci. Technol., 148:321-327.

Ahmide, M. H. and M. H. Abuzogaya (2009). The effect of oral administration of green tea and ginger extracts on serum and hepatic lipid content on serum and hepatic lipid content in rat fed a hyper lipid emic diets. J. of Applied Sci. Res., 5(10): 1709-1713.

Al-Azazi, A. SH.; F. A. Tayeb and T.A. Baraka (2018). Effect of herbal mixture on selected rumen and serum constituents in sheep. Bioscience Res. (3):1653-1660.

Al-jubori, O. S. H. (2017). Synergistic effect of ginger, propolis added to concentrated diet on some production and physiological characteristics of the Awassi ewes. The Iraqi J. of Agric. Sci., 48(2): 582588.

Al-Khayat, D. A. A. (2011). Effect of using Zingiber officinale in the activity and account of Bacteria and Parasital protozoa and Echological status of rumen of Awassi ewes. Alanbar J. Vet. Sci., 1(4): 60-66.

Allam, S. M.; M. A. Ali; A. H. Mohamed and H. A. Sayed, (2012). Impact of different forms of oils on productive performance and conjugated linoleic acid content in goats milk. Egypt. J. Nutr. and Feeds, 15(1):63-73.

Alves, A. C.; N. G. Alves ; I. J. Ascari; F. B. Junqueira; A. S. Coutinho; R. R. Lima; J. R. O. Pérez; S. O De Paula; I. F. Furusho-Garcia and L. R. Abreu (2015). Colostrum composition of Santa Inês sheep and passive transfer of immunity to lambs. J. Dairy Sci., 98:1-11.

Aylin, U. and N. Kocabali (2014) Effect of different dosages of oregano oil on performance and some blood parameters in lambs. Ankara Ankara Üniv Vet Fak Derg, 61: 199-204.

Banchero, G. E.; G. Quintans; G. B. Martin; D. R. Lindsay and J. T. Milton (2004). Nutrition and colostrum production in sheep. 1.Metabolic and hormonal responses to a high-energy supplement in the final stages of pregnancy. Reproduction, Fertility and Development. 16:633-643.

Belewu, M. A. (2006). Conversion of masonia tree sawdust and cotton plant by product into feed by white rot fungus (Pleurotus Sajor caju). African J. of Biotechnology, 5 (6):503-504. 
Benchaar, C.; H. V. Petit; R. Berthiaume; D.R. Ouellet; J. Chiquette and P. Y. Chouinard (2007). Effects of essential oils on digestion, ruminal fermentation, rumen microbial populations, milk production and milk composition in dairy cows fed alfalfa silage or corn silage. J. Dairy Sci., 90:886-897.

Bianchi , A. E.; S. Aleksandro and D. Silva (2014). Effect of adding palm oil to the diet of dairy sheep on milk production and composition; function of liver and kidney, and the concentration of cholesterol, triglycerides and progesterone in blood serum. Small Ruminant Res.,117(1): 78-83.

Boaventura, O. N.; G. M. B. Moreno; S. F. Souza and A. Cannas (2016). Effect of essential oils on dry matter intake and the milk productive and composition in lactating ruminants. Review; Ciênc. vet. tróp., 19:49-57.

Boutoial, K.; E. Ferrandini; S. Rovira; V. García and M. Belén López (2013). Effect of feeding goats with rosemary (Rosmarinus officinalis spp.) by-product on milk and cheese properties. Small Ruminant Res., 112:147-153.

Busquet, M.; S. Calsamiglia; A. Ferret; C. Kamel (2006). Plant extracts affect in vitro rumen microbial fermentation. J. Dairy Sci., 89: 761-771.

Castillejos, L.; S. Calsamiglia; J. Martýn-Tereso and H. Ter-Wijlen (2008). In vitro evaluation of effects of ten essential oils at three doses on ruminal fermentation of high concentrate feedlot-type diets. Anim. Feed Sci. Technol., 145: 259-270.

Dehority, B. A. (1984). Evaluation of sub-sampling and fixation procedures used for counting rumen protozoa. Applied Environment Microbiology, 48: 182-185.

Duncan, D.B. (1955). Multiple range and multiple F- test. Biometris; 11: 1-42.

El-Ashry, M.A.; M.F. Ahmed; S.A. El-Saadany; M.E.S. Youssef; I.A. Gommaa and T.A.A. Deraz (1997). Effect of mechanical vs. mechano-chemical or mechano-biochemical treatments of crop residues on their use in ruminant rations: Digestibility, nitrogen balance and some blood and rumen liquor parameters of sheep. Egyptian J. Nutr. and Feeds, 1: (Special Issue): 173-186.

El-Bassiony, M. F. (2016). Impact of increasing twining rate in Barki ewes on milk yield, milk composition and lambs performance up to weaning. Australian J. Basic and Applied Sci., 10(18): 365-376.

El-Ghousein, Safaa S. (2010). Effect of some medicinal plants as feed additives on lactating Awassi ewe performance, milk composition, lamb growth and relevant blood items. Egypt. J. Anim. Prod., 7(1):3749.

El-Gohary, E. S. H.; S. A. EL-Saadany; M. A. Abd- Elkhabeer and. M. Aiad (2012). Effect of supplementing some medicinal herbs and plants on the performance of lactating goats: 1-productive and reproductive performance. J. Anim. and Poultry Prod. Mansoura Univ., 3(5): 199 - 213.

Fawcett, J. K. and J.E. Soctt (1960). A rapid and precise method for the determination of urea. J. of clinical pathology, 13(2): 156-159.

Fawzi, M.; A. Khlil and A. Atiti (2009).Antifungal effect of some plant extract on Alternaria alternate and fusarium oxysporum. African J. of Biotechnology. 8(11):2590-2597.

Ferme, D.; M. Banjac; S. Calsamiglia; M. Busquet; C. Kamel and G. Avgustin (2004). The effects of plant extracts on microbial community structure in a rumen-simulating continuous-culture system as revealed by molecular profiling. Folia Microbiol (Praha) 49: 151-155.

Gardner, D. S; P. J. Buttery; Z. Daniel and M.E. Symonds (2007). Factors affecting birth weight in sheep: Maternal environment. J. of The society for reproduction and Fertility, 133(1): 297-307.

Giannenas, I.; E. Bonos; E. Christaki and P. Florou-Paneri (2013).Essential Oils and their Applications in Animal Nutrition. Medicinal and Aromatic Plants, 2(6):2-12.

Hameed, O.; H. Hussain and N.H Al- Qudsei (2012).Effect of adding ginger root in the concentrate diet on production of milk and its components in Holstein cattle. Al-Anbar J. Vet. Sci. 5(2):37-43.

Hatch, F.T. and R.S. Lees (1968). Practical methods for plasma lipoprotein analysis. Advances in Lipid Research; 6; 1-68. 


\section{Abo Bakr}

Helal, H.G.; S. Abo Bakr; E.Y. Eid and H.M. El Shaer (2018). Productive performance of Barki ewes fed halophytes added with Propionibacteria freudenreichii under saline conditions. Res. J. Anim. and Vet. Sci., 10 (2):18-27.

Hendawy, A. O.; M. M. Mansour and A. N. M. Nour El-Din (2019). Effects of medicinal plants on haematological indices, colostrum, and milk composition of ewes. J. of Vet. Medicine and Anim. Sci., 2(1):1-5.

Hungate, R.E. (1966).The Rumen and Its Microbes Academic Press, USA.

Hyrslova, S.; G. Krausova; J. Bartova; L. Kolesar and L. Curda (2016). Goat and bovine colostrum as a basis for new probiotic functional foods and dietary supplements. J. of Microbial and Biochemical Technology.,8 (2):56-59.

Ibrahim, N. H.; A. S El-Hawy; M. F. El-Bassiony; F. E. Younis, and S. Abo Bakr (2018). Effect of Feeding Salt Tolerant Plants Silage on Productive Performance and Biochemical Changes of Barki Ewes and their Lambs during the First Month Post-Partum. J. Anim. and Poultry Prod., Mansoura Univ.,9 (8): 337 344.

Ibrhim, I. E. (2015). Effects of dietary herb supplements for ewes on milk contents and some biochemical parameter. Kufa J. For Vet. Medical Sci., 6 (2):170-176.

Kearl, L. C. (1982). Nutrients requirements in developing countries. International Feedstuffs Institute Utah Agric. Exp. Stat.; Utah State University, Logan; USA.

Kedegowda, A. K. G.; L. S. Bionaz; R.A. Piperova; Erdman and J. J. Loor (2009). Peroxisome proliferators activated receptor-y- Activation and long-chain fatty acids alter lipogenic gene networks. In bovine mammary epithelial cells to various extents. J. Dairy Sci., 92:4276-4289.

Kennelly, j.j. (1996). The fatty acid composition of milk fat as influenced by feeding oilseeds. Anim. Feed. Sci. Technol., 60:137-152.

Khalil, M. A.; H.B. Sammour and M.A. El-Wardani (2013). Socio-Economic and Technical Evaluation of Sheep and Goat Farms in North West Cost of Egypt; Egypt. J. Sheep and Goat Sci., 8(1):29-42.

Kholif, S.M.; T.A. Morsy; M.M. Abdo; O.H. Matloup and A.A. Abu El-Ella (2012) Effect of supplementing lactating goats rations with garlic, cinnamon or ginger oils on milk yield; milk composition and milk fatty acids profile. J. Life. Sci., 4(1):27-34.

Kumar, M.; V. Kumar; D. Roy; R. Kushwaha and S. Vaiswani (2014). Application of Herbal Feed Additives in Animal Nutrtion - A Review. Int. J. of Livestock Res., 4(9):1-8.

Lavinia, S.; D. Gabi; D. Drinceanu; D. Stef; M. Daniela; C. Julean; T. Ramona and N. Corcionivoschi ( 2009). The effect of medicinal plants and plant extracted oils on broiler duodenum morphology and immunological profile. Romanian Biotechnological Letters, 14: 4606-4614.

Mech, A.; A. Dhali; B. Prakash and C. Rajkhowa (2008). Variation in milk yield and milk composition during the entire lactation period in Mithun cows (Bos frontalis) Livest. Res. for Rural Develop. 20 :( 5): $1-9$

Mohamed, A.H.; B. E. El-Saidy and I.A. El-Seidy (2003). Influence of some medicinal plants supplementation: 1- On digestibility, nutritive value, rumen fermentation and some blood biochemical parameters in sheep. Egypt. J. Nutr. and Feeds, 6(2): 139-150.

Nanon, A.; W. Suksombata and W.Z. Yangb (2014). Effects of essential oils supplementation on in vitro and in situ feed digestion in beef cattle. Anim. Feed Sci. and Technol., 196:50-59.

Nassar, M. S.; Afaf El Shereef, and S. Abo Bakr (2017). Influence of feeding garlic plant either as powder or oil on reproductive performance of ewes. GSC Biological and Pharmaceutical Sci., 1(3):59-61

Noaman , A. I. and. T. A. Shujaa (2016). Effect of different levels of ginger (Zingiber Officinale) powder roots on the productive performance of Awassi lambs. Third scientific conference of the Faculty of Vet. Medicine, 55-58; Tikrit University. Tikrit, Iraq.

Noaman, A. I. and T. Al-Rawe (2013). Effect of different levels of ginger powder roots on some blood parameters in Awassi lambs. Tikrit J. Agri. Sci., 13(3):245-250. 
Patra, A.K. and J. Saxena ( 2010). A new perspective on the use of plant secondary metabolites to inhibit methanogenesis in ruminants. Phytochemistry, 71: 1198-1222.

Patra, A.K.; D.N. Kamra and N. Agarwal (2010). Effect of extracts of spices on rumen methanogenesis; enzyme activities and fermentation of feeds in vitro. J. Sci. Food Agric.,90: 511-520.

Platel, K. and K. Sirnivasan (2001). Studies on the influence of dietary spices on food transit time in experimental rats. Nutr. Res., 21:1309-1314.

Rakha, G.M. (1988). Studies on the effect of using agro-industrial by-products on health and production of some farm Animal. Ph. D. Thesis Fac. of Vet. Medicine,Cairo Univ., Egypt.

Raltiff ,C.R. and F. Hall (1973). Laborator y Manual of Clinical Biochemistry. Temple; TX; Scott and Memorial Hospital Publication Office.

Russell, J. B. and A. J. Houlihan (2003). Ionophore resistance of ruminal bacteria and its potential impact on human health. Fems. Microbiol. Rev., 27:65-74.

Sallam, S.M.A.; S.A.M. Abdelgaleil; I.C.S. Bueno; M.E.A. Nassera; R.C. Araujo and A.L. Abdalla (2011).Effect of essential oils on ruminal fermentation, microbial population and methane emission in vitro. Options Méditerranéennes; 99:149-156.

SAS (2004). Statistical Analysis System; STAT/ user's guide; Release 9.1; SAS Institute; Cary NC. USA.

Schwarz, S.; C. Kehrenberg and T. R. Walsh (2001).Use of antimicrobial agent In veterinary medicine and food Anim. production. Int. J. Antimicro. Agents., 17: 431-437.

Shams Al-dain, Q.Z. and E.A. Jarjeis (2015). Vital impact of using ginger roots powder as feed additive to the rations of local Friesian dairy cows and its effect on production and economic efficiency of milk and physiological of blood. Kufa J. Vet. Med. Sci., 6:154-165.

Shewita, R.S. and A.E. Taha (2018). Influence of dietary supplementation of ginger powder at different levels on growth performance, haematological profiles, slaughter traits and gut morphometry of broiler chickens, South African J. of Anim. Sci., 48, (6): 998-1008.

Smeti, S.; M. Joy; H. Hajji; J.L. Alabart and F. Muñoz (2015). Effects of Rosmarinus officinalis L. essential oils supplementation on digestion, colostrum production of dairy ewes and lamb mortality and growth. Anim. Sci., 86: 679-688.

Spanghero, M; C. Zanfi; E. Fabbro; N. Scicutella and C. Camellini (2008). Effect of a blend of essential oils on some end products of in vitro rumen fermentation. Anim. Feed Sci. Technol., 145: 364-374.

Stelwagen, K.; E. Carpenter; B. Haigh; A. Hodgkinson and T. T. Wheeler (2009). Immune components of bovine colostrum and milk. J. Anim. Sci., 87:3-9.

Suresh, D. and K. Srinivasan (2007). Studies on the vitro absorption of spice principles-curcumin, Capsaiacin and piperine in rat intestine. Food and Chemical Toxicology, 45:1437-1442.

Warner, A.C.I. (1964). Production of volatile fatty acids in the rumen, Method of measurement. Nutr. Abstract and Review, 34: 339.

Williams, C. A. and E. D. Lamprecht (2008).Some commonly fed herbs and other functional foods in equine Nutrition: A review, The Vet. J., 178:21-31.

Zancan, K. C.; M. O. Marques; A.J. Petenate and M.A. Meireles (2002).Extraction of ginger (Zingiber officinale Roscoe) oleoresin with $\mathrm{CO} 2$ and co-solvents, A study of the antioxidant of the extracts., J. Supercri. Fluids .24(1): 57-67.

Zanouny, A. I.; A. K. I. Abd-El Moty; M. A. A. El-Barody; M.T. Sallam and A. A. Abd El -Hakeam (2013). Effect of supplementation with Nigella Sativa seeds on some blood metabolites and reproductive performance of Ossimi male lambs. Egypt. J. Sheep and Goat Sci., 8 (1):47-56.

Zeweil, H. S.; S. M. Zahran; M. H. Ahmed; Y. M. El-Gindy and A.SH. Khaer (2016). Effect of organic selenium and ginger supplementation of a diet enriched with linseed oil on performance, carcass, blood lipid profile, with its traits in the meat and antioxidant property of growing rabbits. http://www.epsaegypt.com ISSN: 1110-5623 (Print) - 2090-0570 (On line). 


\section{Abo Bakr}

Zhang, T.T.; Z.B. Yang; W.R. Yang; S.Z. Jiang and G.G. Zhang (2011). Effects of dose and adaptation time of ginger root (Zingiber officinale) on rumen fermentation. J. Anim. and Feed Sci., 20: 461-471.

\section{تأثير إضافة مسحوق الزنجبيل أو زيت الزنجبيل على الأداء الانتاجى للنعاج خلال فترة الرضاعة}

\section{صلاح أبوبكر}

قسم تغذية الحيوان واللدواجن ـ شعبة الإنتاج الحيوانس والدواجن ـ مركز بحوث الصحراء ـ المطرية ـ القاهرة ـ مصر.

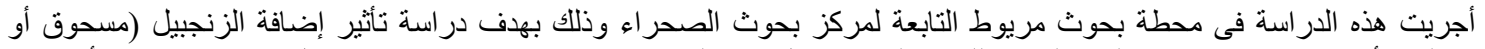

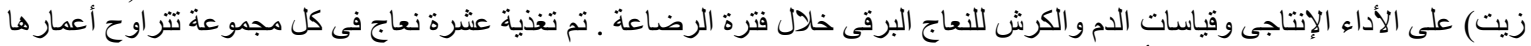

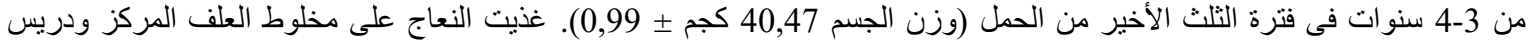

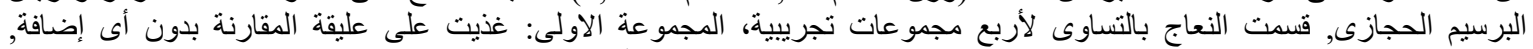

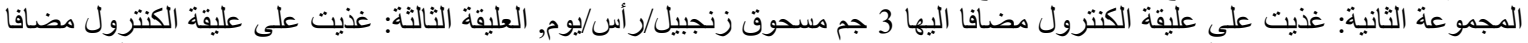

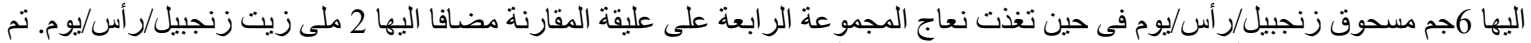
تقدير محصول اللبن كل أسيو عين لعمل التحليل الكيماوى لهأرأخذت عينات سائل الكرش والدم فى منتصف فترة الحليب لعمل التحليلات

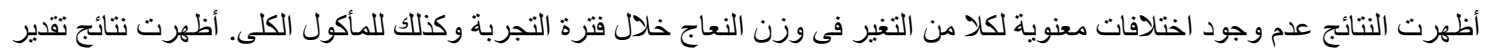

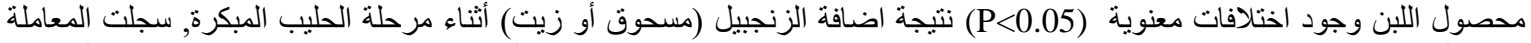

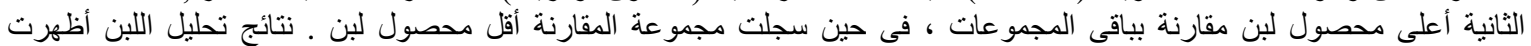

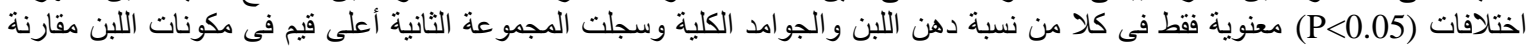

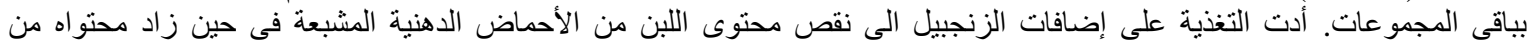
الأحماض الدهنية غير المشبعة.

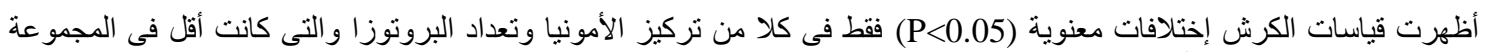

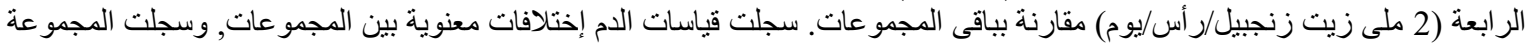

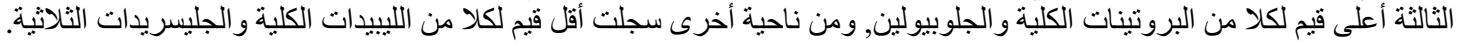

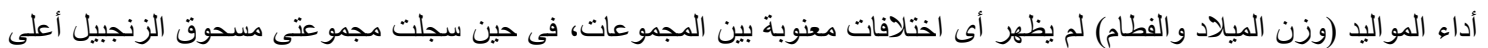

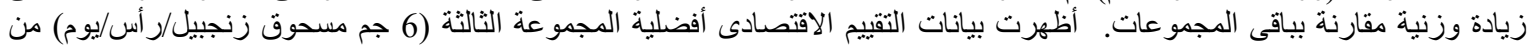

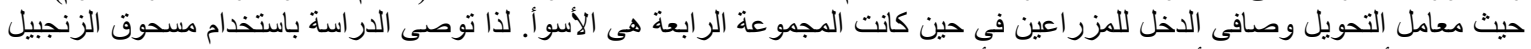

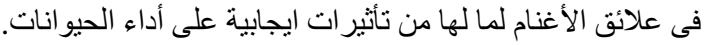

